\title{
Cockayne syndrome with intracranial calcification, hypomyelination, and cerebral atrophy
}

Joe James, James Jose ${ }^{1}$

Departments of Internal Medicine and ${ }^{1}$ Neurology, Government Medical College, Kozhikode, Kerala, India

A 5-year-old boy with global developmental delay was admitted with ataxia of 2-month duration. On examination, he had microcephaly and dysmorphic facies with large ears and sunken eyes. CT head revealed bilateral basal ganglia calcification [Figure 1]. Magnetic resonance imaging brain showed atrophy of cerebrum and hypoplasia of cerebellum, with bilateral symmetrical T2 and T2-fluid-attenuated inversion recovery hyperintensities in periventricular white matter suggestive of hypomyelination [Figure 2]. A diagnosis of Cockayne syndrome (CS) was made based on clinico-radiological features.

CS is a rare multisystem disorder, with autosomal recessive inheritance. It is caused by mutation in either or the two genes CSA or CSB, which is involved in nucleotide excision repair pathway of DNA repair mechanism. Features of CS include physical and mental growth retardation due to postnatal arrest in brain development, characteristic facies with progressive loss of fat and deep set eyes, ocular abnormalities such as cataracts, pigmentary retinopathy and optic atrophy, sensorineural hearing loss, and cutaneous hypersensitivity to ultraviolet rays, but without increased risk of cancer. ${ }^{[1]}$ Imaging findings of CS include bilaterally symmetric calcifications, especially in the putamen, hypomyelination of the supratentorial white matter most pronounced in the periventricular area,

\section{Address for correspondence:}

Dr. Joe James, Njaralakatt House, Pottangadi Road,

West Nadakkav, Kozhikode - 673 011, Kerala, India.

E-mail: drjoejames@gmail.com

\begin{tabular}{|l|l|}
\hline \multicolumn{2}{|c|}{ Access this article online } \\
\hline Quick Response Code: & Website: \\
\hline & www.ruralneuropractice.com \\
\cline { 2 - 2 } & \\
\hline
\end{tabular}

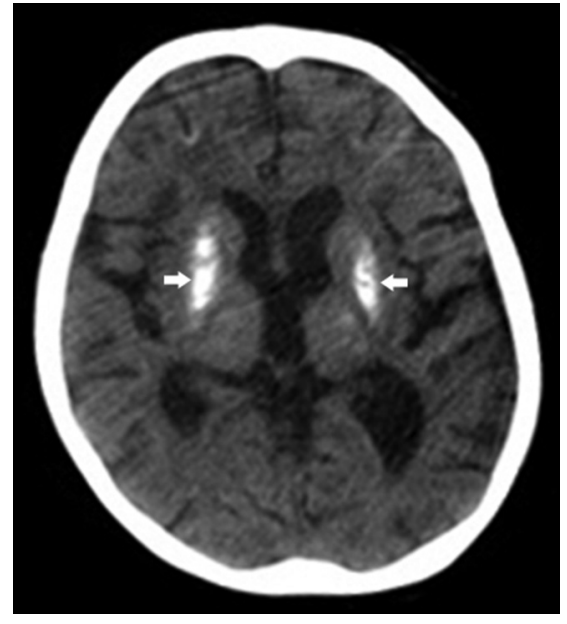

Figure 1: Computed tomography head showing bilateral basal ganglia calcification (arrows)
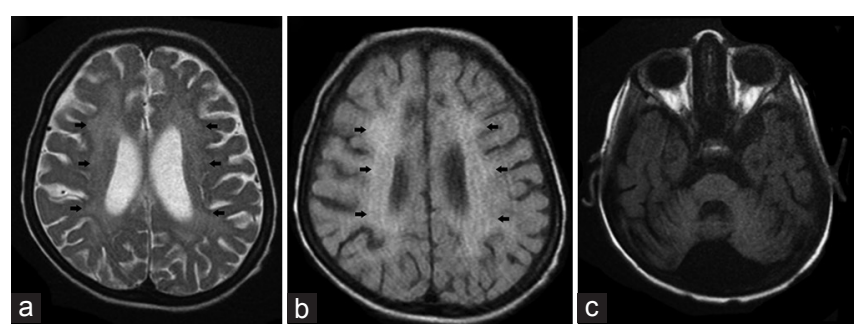

Figure 2: Magnetic resonance imaging brain - axial T2-weighted image (a) and fluid-attenuated inversion recovery imaging (b) showing periventricular hyperintensity suggestive of hypomyelination (arrows). Cerebral hypoplasia is also evident in the images. Axial T1-weighted image (c) at the level of pons showing hypoplasia of cerebellum

global cerebral atrophy with ventricular dilatation and cerebellar atrophy. ${ }^{[2]}$

This is an open access article distributed under the terms of the Creative Commons Attribution-NonCommercial-ShareAlike 3.0 License, which allows others to remix, tweak, and build upon the work non-commercially, as long as the author is credited and the new creations are licensed under the identical terms.

For reprints contact: reprints@medknow.com

How to cite this article: James J, Jose J. Cockayne syndrome with intracranial calcification, hypomyelination, and cerebral atrophy. J Neurosci Rural Pract 2017;8:120-1. 
Financial support and sponsorship

Nil.

\section{Conflicts of interest}

There are no conflicts of interest.

\section{References}

1. Rapin I, Lindenbaum Y, Dickson DW, Kraemer KH, Robbins JH. Cockayne syndrome and xeroderma pigmentosum: DNA repair disorders with overlaps and paradoxes. Neurology 2000;55:1442-9.

2. Koob M, Laugel V, Durand M, Fothergill H, Dalloz C, Sauvanaud F, et al. Neuroimaging in Cockayne syndrome. AJNR Am J Neuroradiol 2010;31:1623-30. 